\title{
Fulminant Type 1 Diabetes with Robust Recovery in Insulin Secretion in a Pregnant Woman as an Initial Manifestation of Third-Trimester Intrauterine Fetal Death
}

\author{
Mi-Hae Seo', Hyosang Han'², Ji Yun Jeong ${ }^{1}$, Jun-Yong Chang' ${ }^{1}$, Sun Young Jung ${ }^{1}$ \\ Departments of ${ }^{1}$ Internal Medicine and ${ }^{2}$ Obstetrics and Gynecology, Soonchunhyang University Gumi Hospital, Soonchunhyang University College of \\ Medicine, Gumi, Korea
}

\begin{abstract}
Fulminant type 1 diabetes mellitus (FT1DM) is a clinical entity in which the process of beta-cell destruction and subsequent progression of hyperglycemia and ketoacidosis are extremely rapid. A 34-year-old woman without any known risk factor for diabetes mellitus experienced a sudden stillbirth at 30 weeks of gestation. She had normal oral glucose tolerance test during pregnancy. Her blood glucose level was $974 \mathrm{mg} / \mathrm{dL}$. Her urine test for ketone bodies was positive. Her hemoglobin A1c level (6.8\%) was near normal range at the first emergency room visit. These findings suggested a very recent onset of diabetes mellitus. Her serum C-peptide level was very low. Islet-related autoantibodies were undetectable. Her clinical course, biochemical, and immunological profiles were consistent with FT1DM. After fluid and insulin based management, beta-cell was rescued with insulin therapy during the evolution of FT1D. At 10 days after admission, maintenance dose of insulin was just 8 unit of insulin once daily. This is the first case of FT1DM with robust recovery in insulin secretion in a pregnant woman who had an initial manifestation of 3rd-trimester intrauterine fetal death in Korea.
\end{abstract}

Keywords: Fulminant type 1 diabetes mellitus; Fetal death; Insulin secretion

\section{INTRODUCTION}

Since its first report in Japan in 1987, fulminant type 1 diabetes has rarely been reported in Southeast Asia [1-3]. Imagawa et al. [1] have described a case of rapid (less than 1 week) onset of diabetes mellitus with rapid development of diabetic ketoacidosis and hyperglycemia at the first diagnosis. The patient showed normal glycated hemoglobin level with pancreatic enzyme elevation without insulin autoantibodies. It was defined as a novel type (fulminant type 1) of diabetes mellitus [1]. In Korea, Jung et al. [4] have reported the first case of fulminant type 1 diabetes without insulin autoantibodies.

Fulminant type 1 diabetes mellitus in pregnancy is known to occur in the third trimester or shortly after delivery [2]. Among cases of fulminant type 1 diabetes mellitus reported from 1991 to 2000 throughout Japan, 13 pregnant women have been reported
$[5,6]$. However, fetal status associated with such pregnancy or changes in blood glucose levels after pregnancy for up to one year has not been reported yet. Only one case of fulminant type 1 diabetes mellitus with vaginal bleeding and fetal death in a 28 -yearold woman who was 33 weeks pregnant was reported in China in 2010 [6].

In Korea, a case of fulminant type 1 diabetes mellitus associated with pregnancy found 4 days after natural delivery was reported in 2007 [7]. However, no case of stillbirth associated with fulminant type 1 diabetes mellitus during pregnancy has been reported in Korea. We experienced a case of fetal death at 33 weeks of gestation associated with maternal fulminant type 1 diabetes mellitus and robust recovery of blood glucose after 10 days of insulin therapy in a pregnant woman who was diagnosed with fulminant type 1 diabetes mellitus and diabetic ketoacidosis. 


\section{CASE REPORT}

A 34-year-old Korean woman in her 33th week of gestation presented with a 3-day history of general fatigue and increased thirst. At emergency room, her plasma blood glucose was $974 \mathrm{mg} / \mathrm{dL}$. She had not been diagnosed with abnormal glucose tolerance.

There was no contraceptive history or no recent medication use. Her obstetric history was 0-0-0-0. There was no specific fetal or maternal condition on prenatal antenatal examination at 2 weeks before admission. The patient felt fatigue for 3 days. Then she couldn't feel the baby moving. So she went to the maternity clinic. Fetal heart sound was not observed at 30 weeks and 3 days of gestation. The patient suspected stillbirth and complained of dyspnea, so she visited our emergency room without examination. She received regular antenatal consultations in the obstetrics clinic. Oral glucose tolerance test (50 g) at 24 weeks of pregnancy was $128 \mathrm{mg} / \mathrm{dL}$. No fetal abnormality was found in amniocentesis at 26 weeks of gestation. She had no family history of diabetes mellitus. There was no smoking history. She drank about one bottle of beer 2-3 times a month.

Fetal and maternal abnormalities were not observed during the prenatal antenatal examination at 2 weeks before admission. The patient felt fatigue for 3 days. She didn't feel fetal movement, so she visited a private maternity clinic at 30 weeks and 3 days of pregnancy. The patient was suspected of having stillbirth with complained of dyspnea. She visited our emergency room without blood test. The patient received regular antenatal consultations in a private obstetrics clinic. Serum glucose was $128 \mathrm{mg} / \mathrm{dL}$ on $50 \mathrm{~g}$ of oral glucose tolerance test at 24 weeks of pregnancy. No fetal abnormality was found during amniocentesis at 26 weeks of gestation.

Upon admission, her blood glucose level were highly elevated $(974 \mathrm{mg} / \mathrm{dL}$ ) and associated with severe ketoacidosis (urine ketone, 3+; arterial blood pH, 7.253; $\mathrm{HCO}_{3}, 11.9 \mathrm{mmol} / \mathrm{L}$ ). Hemoglobin Alc level was 6.9\% (Table 1). Blood ketone was positive.

Serum protein and albumin levels were 7.4 and $4.3 \mathrm{~g} / \mathrm{dL}$, respectively. Liver function tests revealed aspartate aminotransferase and alanine aminotransferase levels of 34 and 17 IU/L, respectively. Kidney function tests showed blood urine nitrogen level of 33.6 $\mathrm{mg} / \mathrm{dL}$ and creatinine level of $1.4 \mathrm{mg} / \mathrm{dL}$. Electrolyte test showed sodium level of $129 \mathrm{mEq} / \mathrm{L}$, potassium level of $5.8 \mathrm{mEq} / \mathrm{L}$, and chlorine level of $86 \mathrm{mEq} / \mathrm{L}$. Serum amylase and lipase levels were 211 and 231 IU/L, respectively. Creatinine clearance rate was 50.1
Table 1. Laboratory findings at admission

\begin{tabular}{|c|c|}
\hline Variable & Value \\
\hline \multicolumn{2}{|l|}{ Complete blood cell count } \\
\hline White blood cell & 9,140/mcL \\
\hline Red blood cell & $438 \times 10^{4} / \mathrm{mcL}$ \\
\hline Hemoglobin & $14.6 \mathrm{~g} / \mathrm{dL}$ \\
\hline Hematocrit & $41.6 \%$ \\
\hline Platelet & $309 \times 10^{3}$ \\
\hline \multicolumn{2}{|l|}{ Carbohydrate metabolism } \\
\hline Glucose & 974 mg/dL \\
\hline Hemoglobin A1c & $6.9 \%$ \\
\hline 1,5-anhydroglucitol & $2.9 \mathrm{mcg} / \mathrm{mL}$ \\
\hline C-peptide & $0.28 \mathrm{ng} / \mathrm{mL}$ (fasting) \\
\hline \multicolumn{2}{|l|}{ Biochemical test } \\
\hline Total protein & $7.4 \mathrm{~g} / \mathrm{dL}$ \\
\hline Albumin & $4.3 \mathrm{~g} / \mathrm{dL}$ \\
\hline Total bilirubin & $0.6 \mathrm{mg} / \mathrm{dL}$ \\
\hline Aspartate aminotransferase & $34 \mathrm{U} / \mathrm{L}$ \\
\hline Alanine aminotransferase & $17 \mathrm{U} / \mathrm{L}$ \\
\hline Alkaline phosphatase & $486 \mathrm{IU} / \mathrm{L}$ \\
\hline Amylase & $211 \mathrm{IU} / \mathrm{L}$ \\
\hline Lipase & $231 \mathrm{IU} / \mathrm{L}$ \\
\hline Blood urea nitrogen & $33.6 \mathrm{mg} / \mathrm{dL}$ \\
\hline Creatinine & $1.4 \mathrm{mg} / \mathrm{dL}$ \\
\hline C-reactive protein & $1.25 \mathrm{mg} / \mathrm{dL}$ \\
\hline \multicolumn{2}{|l|}{ Atrial blood gas } \\
\hline $\mathrm{pH}$ & 7.253 \\
\hline $\mathrm{pCO}_{2}$ & $16.6 \mathrm{~mm} \mathrm{Hg}$ \\
\hline $\mathrm{pO}_{2}$ & $126.8 \mathrm{~mm} \mathrm{Hg}$ \\
\hline $\mathrm{HCO}_{3}$ & $7.2 \mathrm{mmol} / \mathrm{L}$ \\
\hline $\mathrm{BE}$ & $-17.3 \mathrm{mmol} / \mathrm{L}$ \\
\hline \multicolumn{2}{|l|}{ Urinary test } \\
\hline $\mathrm{pH}$ & 5.0 \\
\hline Protein & Negative \\
\hline Glucose & $3+$ \\
\hline Ketone & $3+$ \\
\hline $\mathrm{RBC}$ & Trace \\
\hline \multicolumn{2}{|l|}{ Antibodies } \\
\hline Anti-glutamic acid decarboxylase antibody & Negative \\
\hline Anti-IA-2 & $<0.04 \mathrm{nmol} / \mathrm{L}$ \\
\hline Anti-insulin antibody & $5.30 \%$ \\
\hline Anti-islet antibody & Negative \\
\hline
\end{tabular}

$\mathrm{RBC}$, red blood cell.

$\mathrm{mL} / \mathrm{min}$. Electrocardiogram revealed sinus tachycardia. Due to elevated amylase and lipase levels, acute pancreatitis was suspected and abdominal computed tomography (CT) was planned. Pancreatic edema and diffuse inflammation around the pancreas were identified on abdominal CT. It implied acute pancreatitis with CT severity index 2 (Fig. 1). 


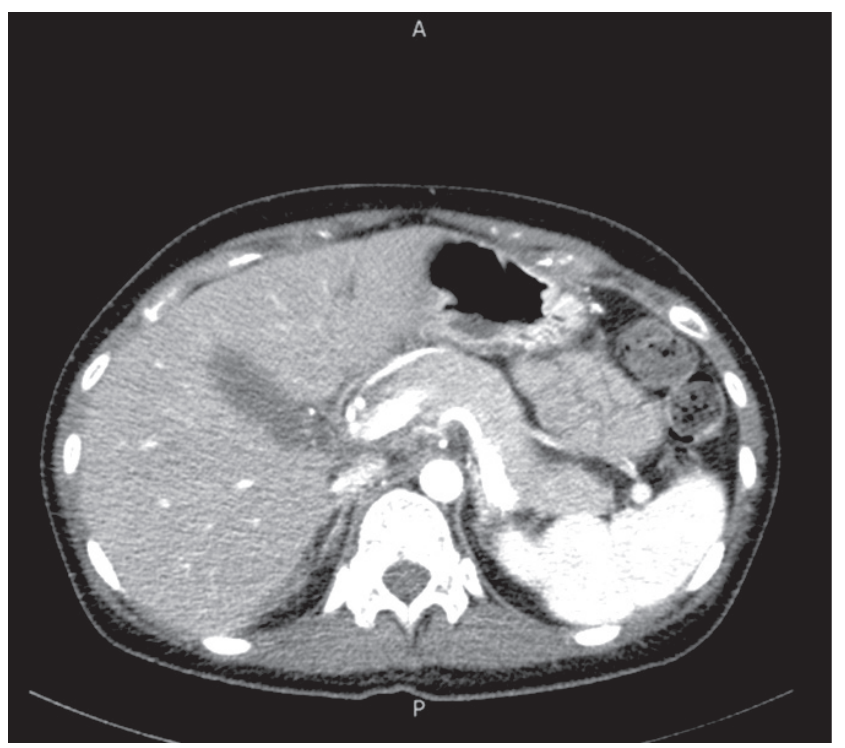

Fig. 1. CT pulmonary angiography scan taken at 2 days after admission showing a mild enlargement of the pancreas and diffuse inflammation of peripancreatic tissues. CT severity index is 2 . CT, computed tomography.

Thus, she was diagnosed with ketoacidosis based on laboratory findings. After treatment with insulin and fluid, her symptoms were improved rapidly. At 10 days after insulin therapy, insulin glargine requirement was only at about 8 units per day. Gastrointestinal symptoms such as nausea and vomiting were improved rapidly after insulin treatment. Such low dose of insulin was maintained. Her blood glucose was controlled well. Insulin was not injected for 3 days (10 to 13 days after admission). On the second day of insulin discontinuity, her fasting blood glucose level was at $139 \mathrm{mg} / \mathrm{dL}, 214 \mathrm{mg} / \mathrm{dL}$ at 2 hours after breakfast, and 159 $\mathrm{mg} / \mathrm{dL}$ at 2 hours after lunch, and $151 \mathrm{mg} / \mathrm{dL}$ at 2 hours after dinner. Her blood glucose level was well controlled without any treatment for 3 days. After that, her fasting blood glucose level was 139 $\mathrm{mg} / \mathrm{dL}$ in the morning before discharge.

Seven days after admission, the obstetrician tried to induce natural delivery of intrauterine fetus. However, no progression was observed. So the patient underwent a cesarean section for the delivery of a stillbirth male (1,030 g).

$\mathrm{C}$-peptide and islet-specific antibody $(\mathrm{Ab})$ were measured at the time of admission to determine the type of diabetes in the patient with diabetic ketoacidosis. Plasma level of C-peptide was $0.28 \mathrm{ng} /$ dL. Her 24-hour-urine C-peptide level was $0.11 \mathrm{ng} / \mathrm{dL}$. Her 1,5-anhydroglucitol level was $2.9 \mathrm{mcg} / \mathrm{mL}$. Anti-insulin $\mathrm{Ab}$ was negative. Glutamic acid decarboxylase (GAD) II Ab level was 0.5 $\mathrm{nmol} / \mathrm{L}$ or less. Islet $\mathrm{Ab}$ was negative. Anti IA-2 level was less than
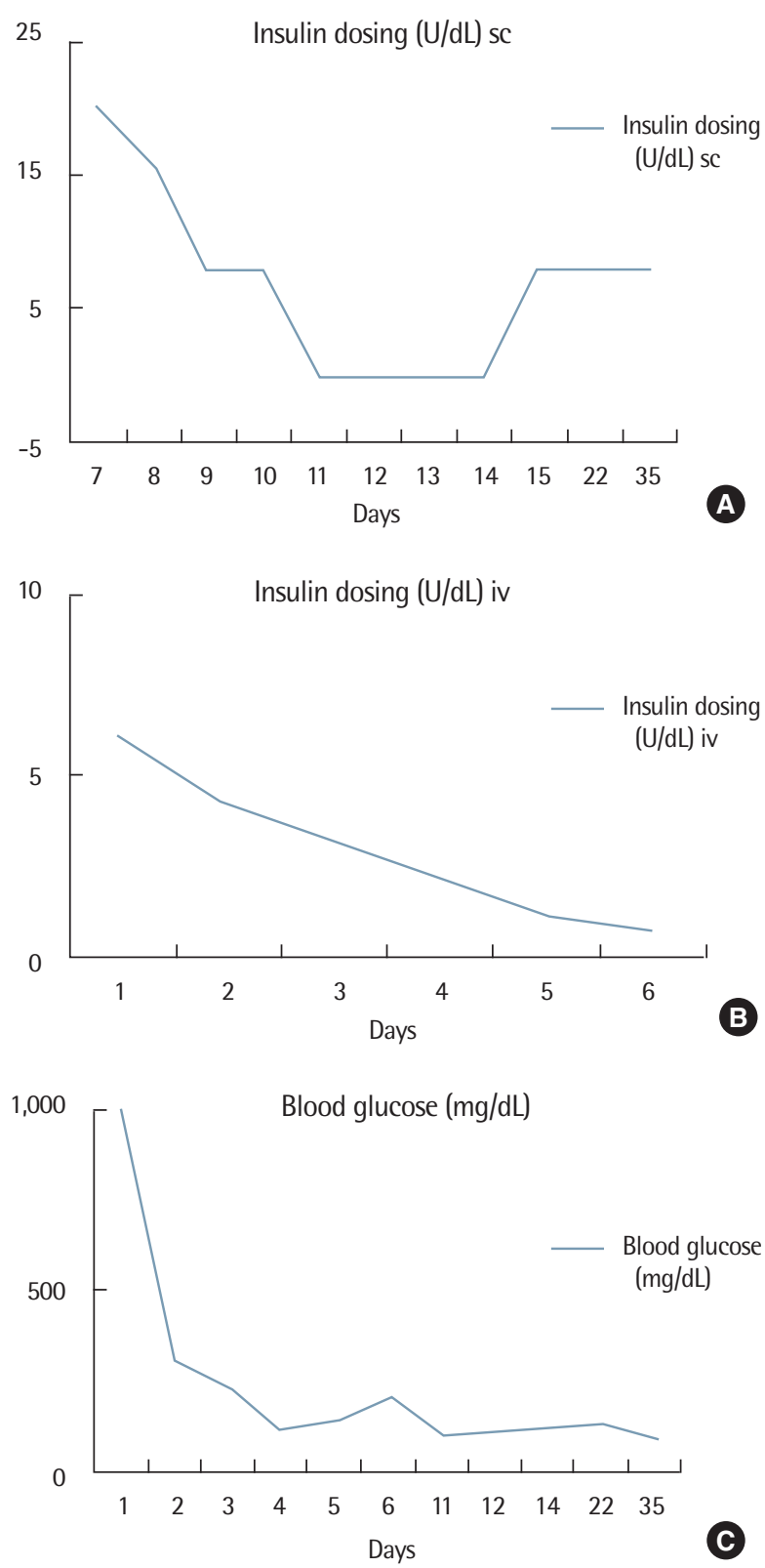

Fig. 2. Fasting insulin dosing (A, B) and blood glucose (C) during day 1 and day 35. sc, subcutaneous; iv, intravenous.

$0.40 \mathrm{nmol} / \mathrm{L}$. All autoantibodies were negative. According to criteria of Imagawa et al. [8] for type 1 diabetes mellitus, all criteria were satisfied and the patient was diagnosed with diabetic ketoacidosis due to fulminant type 1 diabetes mellitus. Regular insulin was injected at $0.1 \mathrm{IU} / \mathrm{hr}$ until the blood glucose level was decreased to $200 \mathrm{mg} / \mathrm{dL}$. The patient maintained stable blood glucose levels at $8 \mathrm{IU}$ of insulin per day after discharge (Fig. 2). We are currently observing her at an outpatient clinic ( 9 months after discharge). Insulin glargine is maintained at 10 units per day. Her 
glycosylated hemoglobin level is $6.1 \%$. She has stable blood glucose level. She is currently undergoing follow-up without significant diabetic complications.

\section{DISCUSSION}

Fulminant type 1 diabetes was first described in Japan in 1987 [1]. Typical symptoms are rapid onset hyperglycemia and diabetic ketoacidosis after brief periods of prodromal symptoms such as fever, influenza-like symptoms, and gastro-intestinal symptoms within a few days. It is accompanied by a sudden loss of pancreatic beta cell function and severe insulin deficiency. Pancreatic islet cell-associated autoantibodies are negative or very low and pancreatic enzyme can be elevated temporarily [5].

Fulminant type 1 diabetes mellitus in pregnancy are characterized by a typical pattern occurring in the 3rd trimester of pregnancy or shortly after postpartum [2]. A study of 10-year incidence of fulminant type 1 diabetes mellitus across Japan has reported 13 cases of fulminant type 1 diabetes mellitus during pregnancy or immediately after childbirth [5].

In 2010, a 28-year-old pregnant woman in China without history of diabetes mellitus presented with massive vaginal bleeding and abdominal pain associated with intrauterine fetal death at 33 weeks of gestation [6]. Her blood glucose level was $612 \mathrm{mg} / \mathrm{dL}$ at the time of admission accompanied by ketoacidosis. Islet cell autoantibodies were all negative. It was reported that her diabetic ketoacidosis was controlled by fluid and insulin treatment [6].

In 2014, a 34-year-old pregnant (24 weeks) woman in Japan presented with nausea without any special medical history [9]. Ultrasound examination showed fetal heart rate and movement in normal range. But the patient complained of severe symptom. She was hospitalized after that she underwent premature rupture of amniotic membranes within 5 hours (preterm infant, female, $592 \mathrm{~g}$ ). On admission, her blood glucose level was $950 \mathrm{mg} / \mathrm{dL}$ and A1c level was $5.7 \%$. She showed ketoacidosis. Islet cell autoantibodies were all negative. Blood glucose was recovered to normal range with insulin and fluid therapy. Her total insulin requirement was around 42 units per day [9].

In 2016, two new cases of fulminant type 1 diabetes were reported in immigrant women (from Laos and the Philippines to New Zealand) [10]. A 36-year-old pregnant woman who migrated from Laos to New Zealand at the age of 19 had four children. She had a natural delivery $(2.28 \mathrm{~kg}$, male) at 36 weeks of gestation with early rupture of membranes. At that time, her blood glucose level was $806 \mathrm{mg} / \mathrm{dL}$. A 42-year-old pregnant woman who came to New Zealand from the Philippines at the age of 38 was admitted at 37 weeks of gestation with abdominal pain and decreased fetal movements. At that time, her blood glucose level was $595 \mathrm{mg} / \mathrm{dL}$. She delivered a male $(3.21 \mathrm{~kg})$.

In Korea in 2016, a 32-week-pregnant woman presented with nausea and abdominal discomfort [11]. Her plasma glucose level was $332 \mathrm{mg} / \mathrm{dL}$. Her A1c and C-peptide levels were 5.6\% and 0.21 ng/mL, respectively. Anti-GAD Ab and anti-Langerhans islets were all negative. She was diagnosed as fulminant type 1 diabetes mellitus and ketoacidosis. She had a normal delivery at 37 weeks of gestation (birth $3.795 \mathrm{~g}$ ) without any perinatal complication [11]. Her blood glucose was regulated by insulin therapy at more than 50 units of insulin daily [11].

Different from cases of fulminant type 1 diabetes mellitus associated with pregnancy reported up to date, in this case, blood glucose is being controlled by 8 units of basal insulin in the present case after about 10 days of fluid and insulin treatment. This is the first case of fulminant type 1 diabetes with robust recovery in insulin secretion in a pregnant woman who had an initial manifestation of 3rd-trimester intrauterine fetal death in Korea.

Imagawa et al. [1] reported the first case of fulminant type 1 diabetes mellitus with negative pancreatic islet autoantibodies and increased pancreatic enzyme levels in 2,000. Recently, Imagawa et al. [8] have revised the diagnostic criteria for type 1 diabetes mellitus in adults in Japan at the Japan Diabetes Society. The criteria for the diagnosis of fulminant type 1 diabetes were: (1) occurrence of diabetic ketosis or ketoacidosis soon (approximately 7 days) after the onset of hyperglycemic symptoms (elevation of urinary and/or serum ketone bodies at first visit); (2) plasma glucose level $\geq 16.0$ $\mathrm{mmol} / \mathrm{L}$ ( $\geq 288 \mathrm{mg} / \mathrm{dL}$ ) and glycated hemoglobin level $<8.7 \%$ at first visit; and (3) urinary C-peptide excretion $<10 \mu \mathrm{g} /$ day or fasting serum C-peptide level $<0.3 \mathrm{ng} / \mathrm{mL}(<0.10 \mathrm{nmol} / \mathrm{L})$ and $<0.5$ $\mathrm{ng} / \mathrm{mL}(<0.17 \mathrm{nmol} / \mathrm{L})$ after intravenous glucagon (or after meal) load at onset. Other findings of fulminant type 1 diabetes mellitus are: (1) islet-related autoantibodies such as antibodies to glutamic acid decarboxylase, islet-associated antigen 2 , and insulin are undetectable in general; (2) duration of the disease before the start of insulin treatment is 1-2 weeks; (3) elevation of serum pancreatic enzyme levels is observed in $98 \%$ of patients; (4) flu-like symptoms (fever, upper respiratory symptoms, etc.) or gastrointestinal symptoms (upper abdominal pain, nausea and/or vomiting, etc.) pre- 
cede the disease onset in 70\% of patients; and (5) the disease can occur during pregnancy or just after delivery. Association with human leukocyte antigen (HLA) DRB1*04:05DQB1*04:01 has been reported [8].

In this case, three criteria for the diagnosis of fulminant type 1 diabetes mellitus and all five findings were satisfactory.

Fulminant type 1 diabetes is known to be caused by interaction between genetic and environmental factors [12]. However, the cause of type 1 diabetes mellitus remains unclear currently. In pancreatic biopsy specimens of these patients, overexpression of major histocompatibility complex class I antibodies was not observed. However, the absence of pancreatic islet inflammation and lymphocytes infiltration were observed in the exocrine tissue of the pancreas. Therefore, the cause of rapid destruction of pancreatic beta cells in such subtype of diabetes mellitus is currently unclear. Non-autoimmune mechanisms such as viral infection might be involved [1]. Kawasaki et al. [13] have conducted a study on type 1 diabetes mellitus throughout Japan from 1973 to 1992 and reported that class II HLA might contribute to the development of fulminant type 1 diabetes mellitus, unlike typical type 1 diabetes.

The frequency of HLA-DR4 was high. However, frequencies of HLA-DR1, DR2, DR5, and DR8 were lower than those of normal controls [14]. On the other hand, in a typical type 2 diabetic patient, the frequency of DR9 is high while the frequency of DR2 is very rare [14]. Reactivation of herpes simplex virus and elevation of IgA autoantibodies to echovirus might be the underlying cause [14]. However, the etiology of fulminant type 1 diabetes mellitus is currently unclear. In pregnancy, immunological paradox (i.e., maternal $\mathrm{T}$ cell tolerance) contributes to the survival of the fetus [15]. Sex hormone such as progesterone also affects immunologic response of $\mathrm{T}$ helper type 2 (Th2) cells and suppresses the appearance of Th1 cells [15].

Both autoimmune thyroid diseases and typical type 1 diabetes are thought to be Th1-related diseases. It has been reported that autoimmune thyroid disease is aggravated during pregnancy by altering the response of Th1 and Th2 cells [16]. This phenomenon is well known in postpartum thyroiditis and autoimmune diseases [16]. The occurrence of postpartum thyroiditis within 1-6 months after delivery has been described as a rebound of cellular immunity [17]. However, type 1 diabetes mellitus that develops during pregnancy or shortly after birth (within 2 weeks) might be caused by a different mechanism from that of postpartum autoimmune disease (i.e., non-autoimmune mechanism) [18]. The eti- ology of fulminant type 1 diabetes mellitus during pregnancy or shortly after birth has not been elucidated yet.

Fulminant type 1 diabetes mellitus can exacerbate the prognosis of pregnant women and fetuses [6]. Therefore, glycemic control during pregnancy is very important because the risk of gynecological complications is greatly increased if gestational diabetes mellitus is not treated. However, it is impossible to predict or prevent fulminant type 1 diabetes mellitus as a regular prenatal test. If symptoms are present, urine ketones and sugars might need to be measured with repeated urine tests [10].

In summary, a case of a pregnant woman without diabetes mellitus, familial history, or risk factors with normal $50 \mathrm{~g}$ oral glucose tolerance test result at 24 weeks of pregnancy presented with stillbirth and dyspnea. Laboratory tests showed hyperglycemia and diabetic ketoacidosis with almost normal Alc level. These results suggested that she developed diabetes very recently. Serum C-peptide concentration was very low. Islet autoantibodies were negative. The patient was diagnosed with fulminant type 1 diabetes mellitus. She was treated with fluid and insulin. She recovered without significant complications after the treatment. Her blood glucose level is well controlled with 8 units of basal insulin once daily.

\section{REFERENCES}

1. Imagawa A, Hanafusa T, Miyagawa J, Matsuzawa Y. A novel subtype of type 1 diabetes mellitus characterized by a rapid onset and an absence of diabetes-related antibodies. Osaka IDDM Study Group. N Engl J Med 2000;342:301-7.

2. Liu L, Mao J, Lu Z, Yan X, Bai X, Ye Y, et al. Clinical characteristics of fulminant type 1 diabetes associated with pregnancy in China. Endocrine 2011;40:408-12.

3. Tan F, Loh WK. Fulminant type 1 diabetes associated with pregnancy: a report of 2 cases from Malaysia. Diabetes Res Clin Pract 2010;90:e30-2.

4. Jung TS, Chung SI, Kim MA, Kim SJ, Park MH, Kim DR, et al. A Korean patient with fulminant autoantibody-negative type 1 diabetes. Diabetes Care 2004;27:3023-4.

5. Imagawa A, Hanafusa T, Uchigata Y, Kanatsuka A, Kawasaki E, Kobayashi T, et al. Fulminant type 1 diabetes: a nationwide survey in Japan. Diabetes Care 2003;26:2345-52.

6. Lee MY, Lin KD, Chang YH, Hsieh MC, Hsiao PJ, Shin SJ. Fulminant type 1 diabetes mellitus leading to fetal loss in a pregnant Chinese woman. Kaohsiung J Med Sci 2010;26:316-20.

7. Yu HK, Nam M, Shim WS, Chung HJ, Kim EJ, Hong SB, et al. A case of fulminant type 1 diabetes associated with pregnancy. J Korean Diabetes Assoc 2007;31:180-3.

8. Imagawa A, Hanafusa T, Awata T, Ikegami H, Uchigata Y, Osawa H, et al. Report of the Committee of the Japan Diabetes Society on the research of fulminant and acute-onset type 1 diabetes mellitus: new diagnostic crite- 
ria of fulminant type 1 diabetes mellitus (2012). J Diabetes Investig 2012;3:536-9.

9. Okuda T, Yamashita S, Ogino Y, Kataoka H, Kitawaki J. An unusual case of fulminant type 1 diabetes during the second trimester of pregnancy. Case Rep Obstet Gynecol 2014;2014:968547.

10. Farrant MT, Rowan JA, Cundy T. Fulminant type 1 diabetes in pregnancy. Intern Med J 2016;46:1212-5.

11. Oh TS, Jung H, Kang HR, Kim TK, Kwon MJ, Lee SH, et al. A case of fulminant type 1 diabetes during pregnancy. J Korean Diabetes 2016;17: 134-8.

12. Imagawa A, Hanafusa T. Pathogenesis of fulminant type 1 diabetes. Rev Diabet Stud 2006;3:169-77.

13. Kawasaki E, Matsuura N, Eguchi K. Type 1 diabetes in Japan. Diabetologia 2006;49:828-36.

14. Imagawa A, Hanafusa T, Uchigata Y, Kanatsuka A, Kawasaki E, Kobayas- hi T, et al. Different contribution of class II HLA in fulminant and typical autoimmune type 1 diabetes mellitus. Diabetologia 2005;48:294-300.

15. Mellor AL, Munn DH. Immunology at the maternal-fetal interface: lessons for T cell tolerance and suppression. Annu Rev Immunol 2000;18: 367-91.

16. Glinoer D, Riahi M, Grun JP, Kinthaert J. Risk of subclinical hypothyroidism in pregnant women with asymptomatic autoimmune thyroid disorders. J Clin Endocrinol Metab 1994;79:197-204.

17. Shimaoka Y, Hidaka Y, Tada H, Nakamura T, Mitsuda N, Morimoto Y, et al. Changes in cytokine production during and after normal pregnancy. Am J Reprod Immunol 2000;44:143-7.

18. Shimizu I, Makino H, Imagawa A, Iwahashi H, Uchigata Y, Kanatsuka A, et al. Clinical and immunogenetic characteristics of fulminant type 1 diabetes associated with pregnancy. J Clin Endocrinol Metab 2006;91:471-6. 